\title{
ANAEROBIC REACTORS WITH BIOFILTER AND DIFFERENT DIAMETER-LENGTH RATIOS IN CASSAVA STARCH INDUSTRY WASTEWATER TREATMENT
}

\section{KATHIA R. KUNZLER ${ }^{1}$, SIMONE D. GOMES ${ }^{2}$, PITÁGORAS A. PIANA ${ }^{3}$, DOUGLAS G. B. TORRES ${ }^{4}$, MARCIO A. VILAS BOAS ${ }^{5}$, MARIA H. F. TAVARES ${ }^{6}$}

\begin{abstract}
The use of anaerobic reactors with media support in the treatment of wastewater from the cassava starch industry has emerged as a viable option because it allows the application of high organic loads and a significant reduction of the HDT needed for the treatment. This research aimed at studying the process of biodigestion in two anaerobic reactors with bamboo support, in the treatment of effluent of cassava starch, by evaluating their performance. The two reactors used present the following diameter: length ratio, 1:6 and 1:3. The organic loads applied to the systems were $0.519,1.156,1.471,3.049,4.347,4.708$ and $5.601 \mathrm{~g} . \mathrm{L}^{-1} . \mathrm{d}^{-1}$. Regarding the efficiency of removal of COD, TS and TVS, no statistically significant differences were obtained between the reactors. The two systems evaluated showed a stable behavior with respect to the VA/TA (volatile acidity/total alkalinity) for all submitted loads. The reactors tended to the maintenance of biogas production as a function of consumed COD for the last three organic loads applied, indicating an ability to withstand higher organic loads.
\end{abstract}

KEYWORDS: biodigestion, organic load, piston flow.

\section{REATORES ANAERÓBIOS COM BIOFILTRO E DIFERENTES RELAÇÕES DIÂMETRO: COMPRIMENTO NO TRATAMENTO DE EFLUENTE DE INDÚSTRIA DE FÉCULA DE MANDIOCA}

RESUMO: A utilização de reatores anaeróbios com meio suporte no tratamento de efluentes líquidos, provenientes das fecularias de mandioca, tem-se apresentado como uma opção viável, uma vez que possibilita a aplicação de cargas orgânicas elevadas e uma redução considerável do TDH necessário para o tratamento. O objetivo do trabalho consistiu no estudo do processo de biodigestão, em dois reatores anaeróbios, com meio suporte de bambu, no tratamento de efluente de fecularia de mandioca, por meio da avaliação do desempenho dos mesmos. Foram utilizados dois reatores com relações diâmetro:comprimento 1:6 e 1:3. As cargas orgânicas aplicadas aos sistemas foram 0,519; 1,156; 1,471; 3,049; 4,347; 4,708 e 5,601 g.L $\mathrm{L}^{-1} \mathrm{~d}^{-1}$. Com relação à eficiência de remoção de DQO, ST e STV, não foram obtidas diferenças estatísticas entre os reatores. Os dois sistemas avaliados apresentaram comportamento estável em relação à AV/AT (acidez volátil/alcalinidade total) para todas as cargas submetidas. Os reatores apresentaram tendência à manutenção da produção de biogás em função da DQO consumida, para as três últimas cargas orgânicas aplicadas, indicando uma capacidade de suportar cargas orgânicas mais elevadas.

PALAVRAS-CHAVE: biodigestão, carga orgânica, fluxo em pistão.

\footnotetext{
${ }^{1}$ Instituto Federal do Paraná (IFPR), Avenida Cívica, 475, 85935-000 - Centro Cívico - Assis Chateaubriand - PR - Brasil, Kathia.kunzler@ifpr.edu.br.

${ }^{2}$ Universidade Estadual do Oeste do Paraná-UNIOESTE, Programa de Pós-Graduação em Engenharia Agrícola. Rua Universitária, 2069, 85819-210, Cascavel, PR, Brasil. (RHESA) Simone.gomes@unioeste.br.

${ }^{3}$ Universidade Estadual do Oeste do Paraná-UNIOESTE, Programa de Pós-Graduação em Conservação e Manejo de Recursos Naturais. Rua Universitária, 2069, 85819-210, Cascavel, PR, Brasil. pitapiana@yahoo.com.br (PAP).

${ }^{4}$ Universidade Estadual do Oeste do Paraná-UNIOESTE, Programa de Pós-Graduação em Eng. Agrícola, douglasgbtorres@hotmail.com.

${ }^{5}$ Universidade Estadual do Oeste do Paraná-UNIOESTE, Programa de Pós-Graduação em Eng. Agrícola, vilasboas@unioeste.br.

${ }^{6}$ Universidade Estadual do Oeste do Paraná-UNIOESTE, Programa de Pós-Graduação em Eng. Agrícola, mhstavar@gmail.com. Recebido pelo Conselho Editorial em: 20-12-2010
}

Aprovado pelo Conselho Editorial em: 15-1-2013 


\section{INTRODUCTION}

Interest in the anaerobic treatment of liquid and solid wastes from farming and agribusinesses has increased significantly in recent decades, due to the advantages presented by this, compared to common used wastewater aerobic treatment processes (LEITE et al., 2009; RODRIGUES et al. 2010).

One of the limiting factors in the use of anaerobic treatment systems, is the application of effluents with low organic loads, considering that heavy loads can cause acidification of the systems (CHERNICHARO, 2007).

One alternative that has shown to be effective due to the possibility of using higher organic loading in anaerobic reactors is the use of a support, since it provides an increased contact area with the effluent of microorganisms and better fixation thereof, in providing high biomass retention, increased maximum load supported by the system, which may result in reduced detention time required for treatment (COLLIN et al., 2006; FIA et al., 2010; ORTIGARA et al. 2010).

The use of support material enables the growth of high fixed biomass concentration, which gives advantages when compared to microorganisms in suspension, allowing more efficient and more compact systems (ORTIGARA et al. 2010).

BORGES et al. (2009) highlights that the adoption of the support material offers good conditions for starting the reactors, since it offers good conditions for biomass adaptation, resistance to load shocks, and resistance at room temperature, which possibilities their use in a wide variety of effluents.

In accordance with ABREU \& ZAIAT (2008) the retention of biomass within anaerobic reactors is a decisive factor for the treatment process, as loss of biomass negatively influences the performance of treatment, and, according to the authors, an efficient way to avoid this loss is their immobilization with a support material, favoring the formation of biofilms and better retention of microorganisms in the reactor.

KUCZMAN et al. (2011) commented that the use of a support contributes to the increase in specific production of biogas per volume of reactor besides decreasing the hydraulic retention time.

Many are the studies realized that use anaerobic reactors with half support for the treatment of different types of waste, among them it is possible to mention the use by RODRIGUES et al. (2010) in the treatment of swine wastewater, FIA et al. (2010) in the treatment of wastewater from processing coffee fruits, GIUSTINA et al. (2010); XIE et al. (2010); QIU et al. (2010) in the treatment of domestic wastewater and ORTIGARA et al. (2010) in winery wastewater treatment. Although the characteristics of the effluent vary, all authors obtained satisfactory results when using this type of system.

Regarding the support, different kinds of materials, minerals or synthetic ones, has been employed in anaerobic treatment systems (GIUSTINA et al. 2010). Among the materials used are oyster shells and plastic spheres (XIE et al. 2,010), ceramic and carbonate rock (QIU et al. 2,010), crushed granite (FIA et al. 2,010 b) furnace slag, polyurethane foam (FIA et al., 2010), PVC (PINTO \& CABELLO, 2007; TORRES, 2009), bamboo (Torres, 2009).

SANTOS and OLIVEIRA (2011) evaluated the performance of four horizontal anaerobic reactors for treating swine wastewater using different forms of biomass retention as sludge blanket, bamboo rings as support, corrugated conduit plastic rings and bushing rings, and concluded that it is possible to apply high concentrations of particulate organic matter and capture large amounts of methane at low hydraulic retention time, confirming that the use of a support contributes to the increased efficiency of anaerobic systems.

The anaerobic digestion is a natural process that occurs in oxygen-free environments where microorganisms decompose organic matter (LIU et al., 2008) recovering energy in the form of biogas. 
The liquid waste from cassava starch factories are characterized by high organic load resulting from high concentrations of carbohydrates, and the presence of cyanide ion and hydrogen cyanide, substances that can act by blocking the transport of oxygen in living beings, thus favoring the action of anaerobic bacteria and making the ideal environment for their development (PINTO \& CABELLO, 2007), therefore favoring the use of anaerobic systems for this type of effluent.

When evaluating the performance of the reactors is indicated to define the hydraulic model assigned to them, so that one can calculate the concentration of the compound in the effluent (VON SPERLING, 1996). The hydraulic model of the reactor is the type of flow and mixing pattern which depends on the geometry of the reactor.

In this context, the aim of this study was to evaluate the process of anaerobic digestion of liquid waste from the cassava starch industry in two continuous flow monophasic horizontal reactors, with different diameter: length ratios, using bamboo as a support.

\section{MATERIAL AND METHODS}

\section{Effluent}

The effluent used as substrate for anaerobic digestion was collected in a cassava starch factory located in the city of Toledo, State of Parana - Brazil. During the processing of the cassava root for obtaining the starch, the industry reuses the water discarded of the starch extraction process for the cleaning of roots, therefore, the effluent used consisted of starch extraction water and root washing water.

The collection of effluent was performed when it was discarded by the industry, before the conduction of any treatment.

After collection, the effluent was immediately transported to the Laboratory of Environmental Sanitation of the Universidade Estadual do Oeste do Paraná (State University of West Paraná), Cascavel campus, where the experiment was conducted.

In order to simulate a condition closer to the real, no corrections were made for $\mathrm{pH}$ or dilution of the effluent, which is used in its raw form, performing only homogenization and storage in a freezer until the time of use.

For characterization of the effluent, $\mathrm{pH}$, chemical oxygen demand (COD), total solids (TS) and total volatile solids (TVS) were analyzed.

\section{Reactors}

The anaerobic reactors used were made of PVC pipe with two diameter: length ratios. The first reactor had a diameter of $15 \mathrm{~cm}$ and a length of $90 \mathrm{~cm}$, resulting in a diameter: length ratio of $1: 6$, and the second had a diameter of $20 \mathrm{~cm}$ and a length of $60 \mathrm{~cm}$, resulting in relative diameter: length ratio of $1: 3$.

Bamboo rings of $10 \mathrm{~cm}$ long, in average, and diameter ranging between 1.7 and $2.5 \mathrm{~cm}$ were used as support. The useful volume of the reactor was estimated to 6.8 to $6.0 \mathrm{~L}$, and the diameter: length ratio of 1:3 and 1:6, respectively. The reactors were fed in a continuous flow.

\section{Inoculum}

The inoculum used in the reactors was from the anaerobic pond of the system for effluent treatment of the industry. It was collected at the same points of eruption of gases located in the middle of the pond, due to the drag of mud from the bottom of the pond to the surface during the eruption of gases, thus enabling obtaining of a higher inoculum concentration of total volatile solids.

The inoculum used in the experiment was characterized and presented results for COD of $1271.80 \mathrm{mg} \mathrm{L}^{-1}$, TS $3587.50 \mathrm{mg} \mathrm{L}^{-1}$, TVS $1027 \mathrm{mg} . \mathrm{L}^{-1}$ and STF of $2560.00 \mathrm{mg} . \mathrm{L}^{-1}$. 
For inoculation, 30\% of the useful volume of the reactors was filled with inoculum and $10 \%$ of cassava wastewater, the remainder being filled with distilled water. For adaptation of microorganisms to the system and the stabilization of the reactors, initially low organic loads were applied, which were increased gradually after checking the stability, evidenced by the parameters $\mathrm{pH}$, volatile acidity (VA), total alkalinity (TA) and biogas production.

\section{Supply of reactors and measurement of biogas}

For supplying the reactor a peristaltic pump was used in which the volume of the effluent was distributed throughout the day, with the aid of a timer. The measurement of the amount of biogas produced was carried out by means of a gasometer system connected to the reactors, as shown in Figure 1.

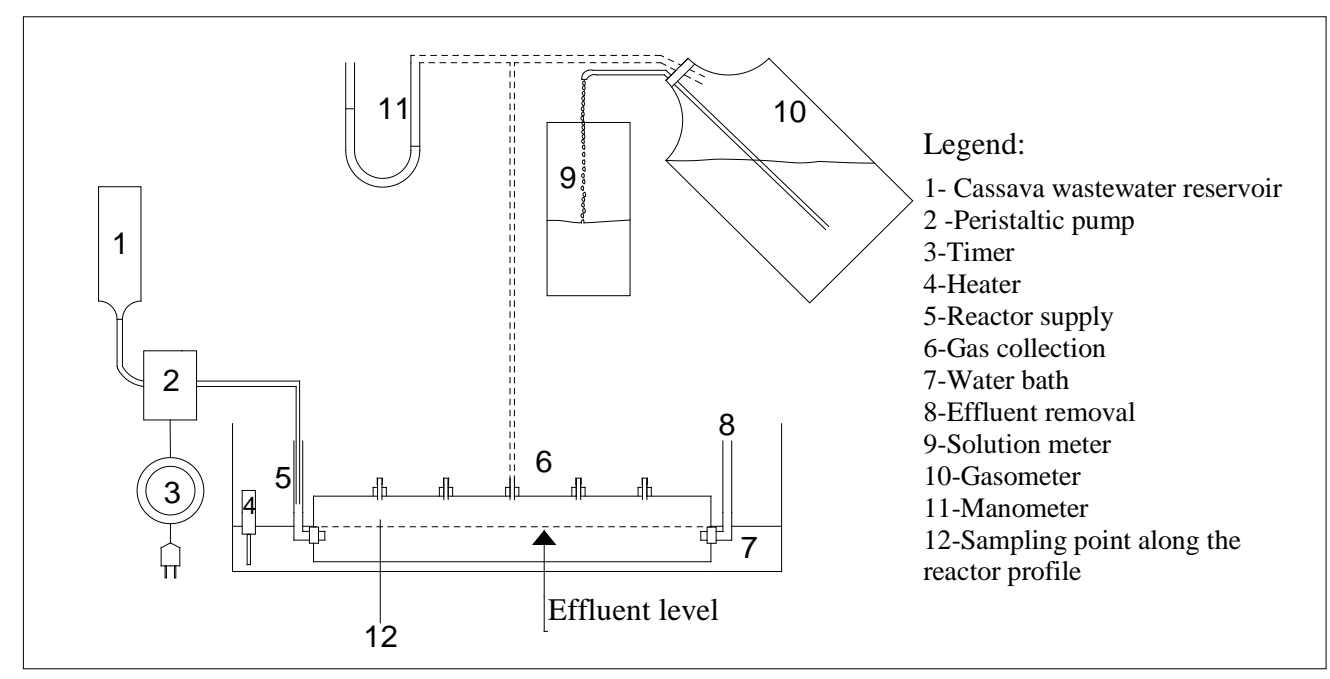

FIGURE 1. Scheme of anaerobic digestion system and measurement of biogas produced.

The two reactors remained submerged in a water bath with controlled temperature ranging from $26^{\circ} \mathrm{C}$ to $28^{\circ} \mathrm{C}$.

In order to measure the volume of biogas with all its constituents (methane, $\mathrm{CO}_{2}, \mathrm{H}_{2} \mathrm{~S}, \mathrm{H}_{2} \mathrm{O}$, etc.) an acidified saline solution with $3 \%$ of $\mathrm{H}_{2} \mathrm{SO}_{4}$ and $25 \%$ of sodium chloride was used in the gasometer.

\section{The experiment}

Seven volumetric organic loads were applied to the reactors, as shown in Table 1. All loads were gradually increased in order not to overload and cause a destabilization of the systems.

TABLE 1. Organic loads and their respective times of hydraulic retention applied to the systems.

\begin{tabular}{ccc}
\hline Treatment & Load $\left(\mathrm{gCOD} \cdot \mathrm{L}^{-1} \cdot \mathrm{d}^{-1}\right)$ & HDT $(\mathrm{d})$ \\
\hline 1 & 0.519 & 9.00 \\
2 & 1.156 & 7.00 \\
3 & 1.471 & 5.50 \\
4 & 3.049 & 4.00 \\
5 & 4.347 & 2.15 \\
6 & 4.708 & 2.80 \\
7 & 5.601 & 2.70 \\
\hline
\end{tabular}

A daily monitoring was conducted for each applied load by analysis of $\mathrm{pH}$, biogas production and relation VA/TA, in order to check the time the system was stable. 
After the stability of the reactors was checked, analyzes were carried out daily during the period of fifteen days, for each volumetric organic load applied to evaluate the performance of the process by means of the parameters COD, TS, TVS, VA/TA ratio and biogas production.

To determine the parameters of total solids, total volatile solids and chemical oxygen demand, methods 2540B and 5220D were adopted, described in (APHA, 2005). Analysis of Volatile Acidity and Total Alkalinity were made according to SILVA (1977).

\section{Statistical Design}

For reactor performance results related to applied organic loads, the bifactorial variance statistical analysis (parametric ANOVA), with the aid of the Statistica 7.0®, was carried out. In this analysis, the diameter: length ratio of the reactors and applied organic load were considered categorical variables and the results for removal of COD, removal of solids, removal of total volatile solids, biogas specific production in terms of removed COD and VA/TA ratio, as response variables.

For the response variables that showed significant interaction effect for only one of the categorical variables, there was a one-factor analysis of variance (unifactorial ANOVA).

Differences between the averages were evaluated by Tukey's test $a$ posteriori to significance level of $5 \%(p<0.05)$.

\section{RESULTS AND DISCUSSION}

\section{Effluent characterization and applied loads}

Table 2 shows the results obtained for the characterization of the effluent used in the research.

TABLE 2. Characterization of effluent parcels used during the experiment.

\begin{tabular}{|c|c|c|c|c|}
\hline Load $\left(g_{C O D} \cdot L^{-1} \cdot d^{-1}\right)$ & COD (mg.L $\left.\mathrm{L}^{-1}\right)$ & TS (mg. $\left.\mathrm{L}^{-1}\right)$ & VTS (mg.L $\left.{ }^{-1}\right)$ & STF (mg.L L $\left.^{-1}\right)$ \\
\hline 0.519 & 4670.25 & 9125.00 & 7205.00 & 1920.00 \\
\hline 1.156 & 8091.20 & 12042.50 & 9460.00 & 2582.50 \\
\hline 1.471 & 8091.20 & 12042.50 & 9460.00 & 2582.50 \\
\hline 3.049 & 12194.53 & 9670.00 & 7865.00 & 1805.00 \\
\hline 4.347 & 9346.00 & 12797.00 & 6470.00 & 6327.00 \\
\hline 4.708 & 13181.10 & 11345.00 & 6836.75 & 4508.25 \\
\hline 5.601 & 15121.80 & 11422.50 & 9520.00 & 1902.50 \\
\hline KUCZMAN et al. (2007) & 15720 & 9544 & 7510 & 2034 \\
\hline PINTO \& CABELLO (2007) & 14300 & 9800 & 6000 & 2400 \\
\hline
\end{tabular}

It is observed in Table 2 that for the loads 1.156 e 1.471 gCoD $\cdot \mathrm{L}^{-1} \cdot \mathrm{d}^{-1}$ the characteristics of the effluent used is the same. Since the same batch of effluent was used for these two treatments due to the gathering of a large volume of effluent.

Based on the results presented in Table 2 it can be seen that the composition of the batches of waste used were similar to those presented by the authors mentioned. It is possible to observe variations in the effluent samples used due to being operated on different days, however, they may be explained due to the characteristics of the root interfere with the characteristics of waste generated, and many factors may affect the composition of cassava, including the time, the type of soil, temperature, altitude, humidity and cultivar (RIBAS \& BARANA, 2003).

\section{Efficiency of the reactors regarding the removal of organic matter, total solids and total} volatile solids

By using statistical analysis of bifactorial ANOVA, working with the mean values $\pm 95 \%$ of confidence interval (CI), it was obtained for the parameters of the performance of reactors, removal 
of COD, removal of TS and specific production of biogas as a function of COD consumed, a significant interaction effect $(\mathrm{p}<0.05)$, suggesting that both the loads applied to the different diameter: length ratios of the reactors, influenced these response variables, as shown in Figure 2 (a), (b) and (d).

For the indicator variable removal of TVS, there was no significant interaction effect between applied loads and diameter: length ratio of the reactors, since the results obtained by bifactorial ANOVA for p value exceeded 5\%, as shown in Figure 2 (c). By this analysis it was possible to observe that only loads applied to the reactors have any influence on the removal of total volatile solids, thus obtaining a significant effect with a p value of less than 0.05 , proved by the unifactorial ANOVA as shown in Figure 2 (c).

Differences between averages were evaluated by Tukey's test a posteriori, adopting the level of $5 \%(p<0.05)$ of significance for all analyzes.
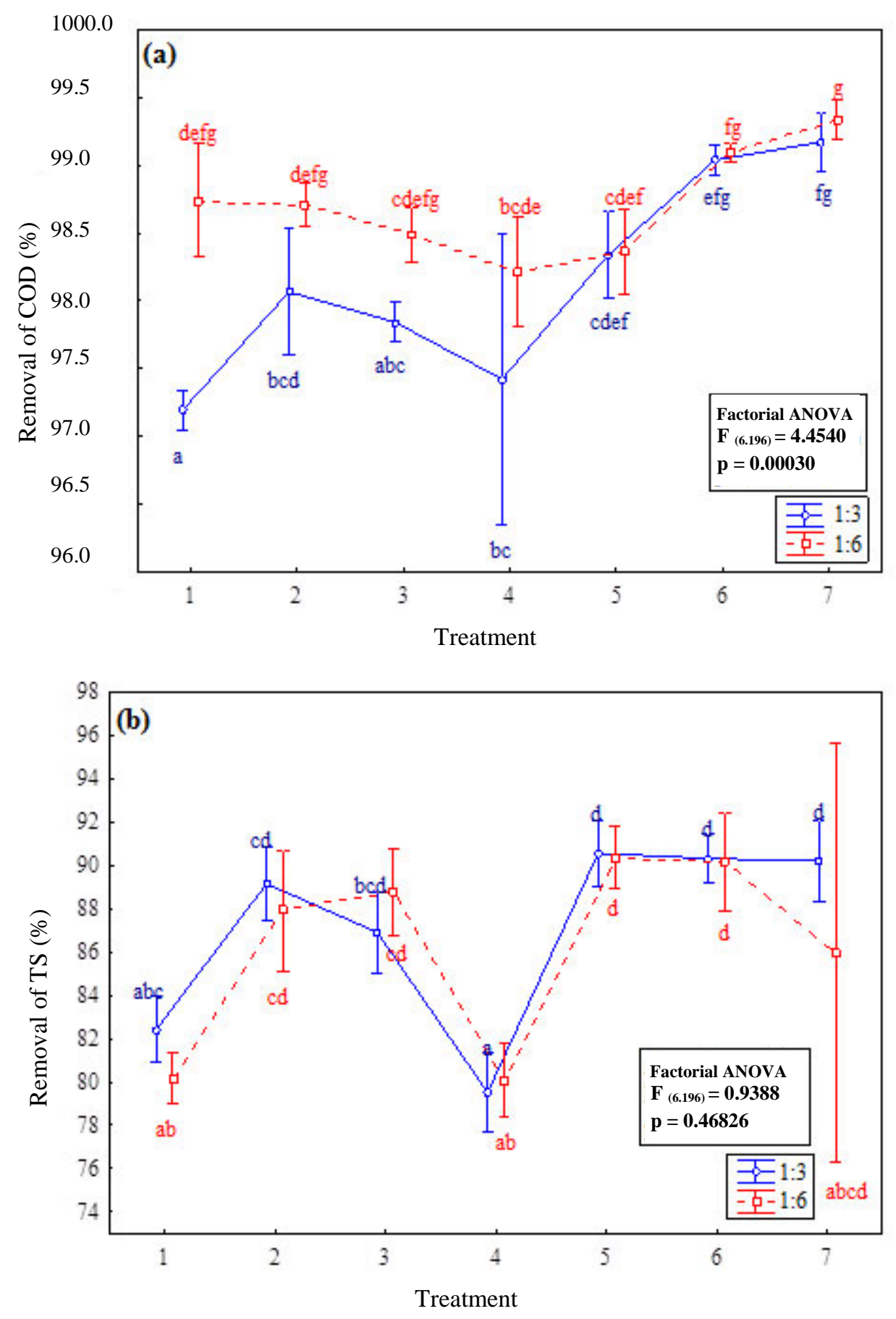

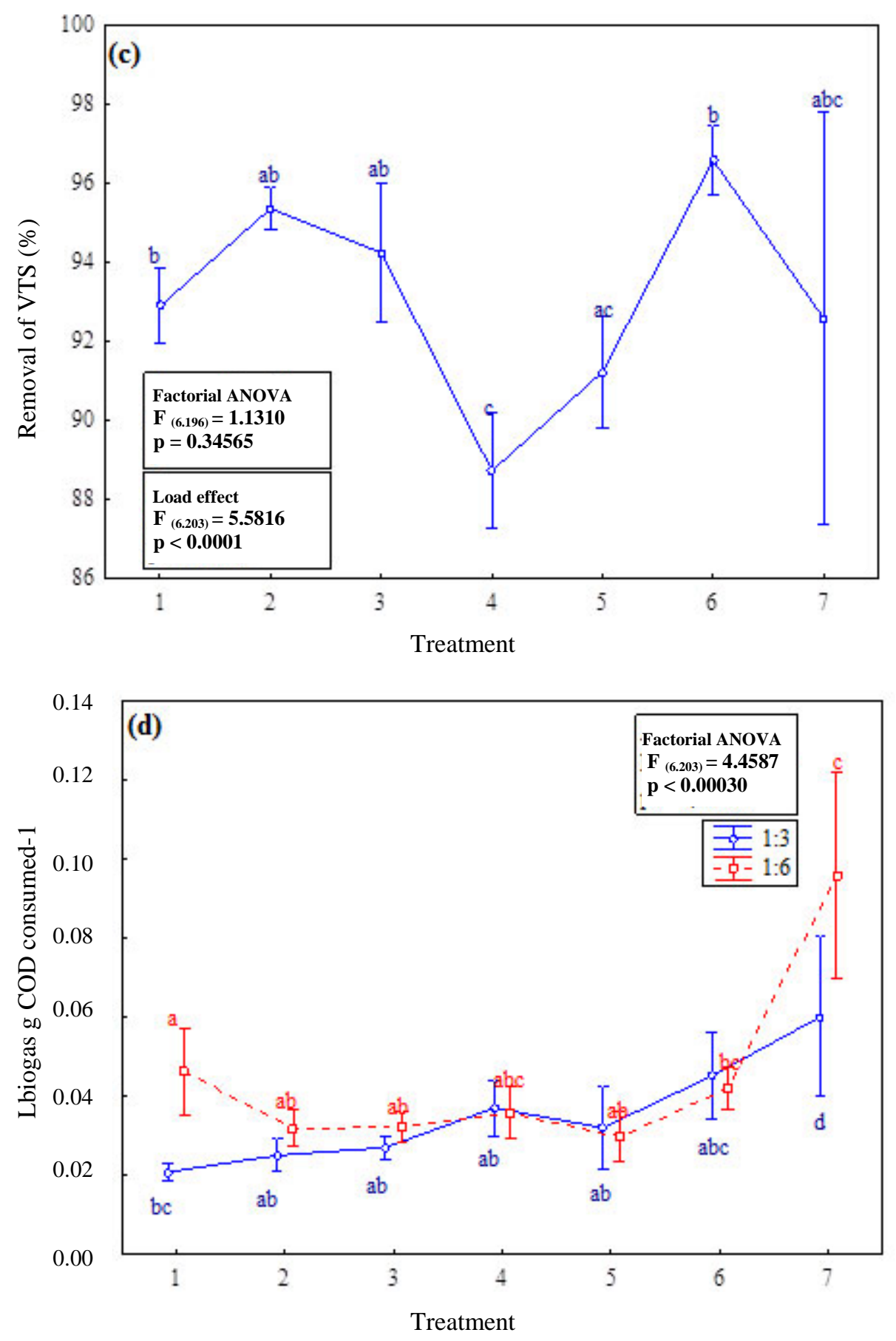

* Different letters indicate significant differences $(\mathrm{p}<0.05)$ by Tukey’s test a posteriori.

FIGURE 2. Values of variables indicating the performance of reactors for the different loads and diameter: length ratios (average of $\pm 95 \%$ IC). (A) removal of COD; (b) removal of TS; (c) VTS removal; (d) biogas specific production as a function of COD consumed.

In relation to the efficiency of the reactors regarding the removal of organic matter (COD), as observed in Figure 2 (a), the results obtained by the Tukey's test showed that statistically significant differences were observed only for the $0.519 \mathrm{gCOD} . \mathrm{L}^{-1} \cdot \mathrm{d}^{-1}$ load, Treatment 1 . This difference was due to the destabilization of the reactors at the beginning of their operation.

For the last two organic loads applied, a tendency to maintain the removal efficiency of organic matter in the reactors was noted, indicating that the two reactors are able to withstand higher organic loads. 
For the latest organic load applied, of 5.601gCOD.L $\mathrm{L}^{-1} \cdot \mathrm{d}^{-1}$, average removals of COD of 98.33 and $99.17 \%$ for the reactors $1: 6$ and $1: 3$, respectively, were obtained.

As only the first organic load applied promoted a statistically significant difference compared with other treatments, regarding the load applied and the type of reactor, it is observed that by using bamboo as support in treating cassava starch anaerobic effluent, diameter: length ratios of the reactors did not influence the removal of organic matter to the applied loads.

When evaluating the efficiency of COD removal in two reactors of equal size, but different supports - bamboo and PVC - TORRES (2009) obtained differences in the removal of organic matter between the two reactors, working with organic loads of $0.55,1.16,1.47$ and $3.05 \mathrm{~g} . \mathrm{L}^{-1} \mathrm{~d}^{-1}$. The removal observed when applying the load of $3.05 \mathrm{~g} . \mathrm{L}^{-1} \mathrm{~d}^{-1}$ was of $97.79 \%$ for the reactor with PVC and $98.48 \%$ for the reactor with bamboo. The results showed that the use of bamboo as support had a higher COD removal efficiency and a tendency to withstand higher organic fillers.

COLIN et al. (2006), worked with an anaerobic reactor of 6.54L of volume, used bamboo as a support for the treatment of cassava wastewater, which reached a maximum load of COD of 11.8g. $\mathrm{L}^{-1} \mathrm{~d}^{-1}$, and, for this load, 87\% of removal of COD.

KUCZMAN et al. (2007), working with a horizontal continuous flow reactor without a support, for the anaerobic treatment of cassava wastewater, obtained the maximum load supported by the reactor of 2,96gCOD.L ${ }^{-1}$. day ${ }^{-1}$, with removal of COD of 95.31\%. Comparing these data with those obtained in this study, it is possible to observe that the bamboo as support promoted an increased system capacity in supporting higher organic loads.

PINTO \& CABELLO (2007), when working with a set of two anaerobic digesters (acidogenic and methanogenic) of upflow, using PVC ring as the support, obtained removal of COD of $84 \%$ for a load input of 14.291g. $\mathrm{L}^{-1} \cdot \mathrm{d}^{-1}$. Comparing the results obtained by these authors with those found in this study, it is observed that higher values were found regarding the removal of organic matter. However, the applied load for this study was lower than the organic charge applied thereto.

Regarding the efficiency of the reactors about the removal of solids, it is possible to observe in Figure 2 (b), by the results obtained by the Tukey's test, that the results showed no statistical differences between the reactors, indicating that when using bamboo as a biofilter, the two diameter: length ratios of the reactors did not influence on the removal of the TS, as observed for the removal of organic matter.

For this parameter, values of removals of 85.96 and $90.20 \%$ with respect to the reactor diameter: length ratio of 1:6 and 1:3, respectively, for the highest applied load, were obtained.

RIBAS \& BARANA (2003), when evaluating a monophasic reactor filled with hoses arranged vertically as support with a volume of 1.98 liters for the treatment of cassava wastewater, obtained efficiency of removal of total solids of $44 \%$ by working with HDT of 9.6 days and organic load of 2.9gCOD.L $\mathrm{L}^{-1} . \mathrm{d}^{-1}$ and 58\%, when they applied a load of $0.86 \mathrm{gCOD} . \mathrm{L}^{-1} . \mathrm{d}^{-1}$ with HDT of 4 days. Comparing with the results obtained in this study, in which the higher applied load was 5.601gCOD. $\mathrm{L}^{-1} \cdot \mathrm{d}^{-1}$ with HRT of 2.7 days, it is possible to observe that the use of bamboo as a support medium provided greater efficiency Removal ST, the application of higher organic loading and decrease in HDT, improving the efficiency of the system.

KUCZMAN et al. (2007), worked with the treatment of cassava wastewater, but in an anaerobic reactor without phase separation, and achieved efficiencies of $77 \%$ regarding the removal of TS, to the maximum load of COD supported by the system of $2.96 \mathrm{gL}^{-1} \mathrm{~d}^{-1}$.

Comparing the results obtained in this study with those obtained by KUCZMAN et al. (2007) it was observed that with the use of bamboo as support, it was obtained a removal of TS efficiency of 90.20 and $85.96 \%$ for input load of $5.6 \mathrm{gL}^{-1} \cdot \mathrm{d}^{-1}$, demonstrating the possibility of applying greater organic loads to those systems. 
Regarding the results obtained for the removal of volatile solids (Figure 2c), statistical analysis showed that no differences have occurred between the reactors, corroborating the results obtained for the removal of organic matter and solids. Among the applied loads no statistically differences were observed by the Tukey's test a posteriori.

It was obtained an average efficiency of $92.56 \%$ for both reactors for load 5.601gCOD. $\mathrm{L}^{-1} \cdot \mathrm{d}^{-1}$ (treatment 7).

COLIN et al. (2006) studied the anaerobic treatment of cassava wastewater in reactor with bamboo as support and its volume was of 6.52 liters, obtained values of removal of total volatile solids of $74.2,66.3,69.1,70.2,68.5$ and $68.2 \%$ for $1.1,2.3,5.3,7.6,9.6$ and $11.8 \mathrm{gL}^{-1} . \mathrm{d}^{-1}$ COD loads, respectively.

KUCZMAN et al. (2007) evaluated the removal of TVS in a monophasic anaerobic reactor without the use of supports for the treatment of cassava wastewater. The authors achieved efficiencies of 99.5 , 98.9 and $89.5 \%$ for the organic loads of $1.28,1.57$ and $2.68 \mathrm{gL}^{-1} . \mathrm{d}^{-1}$, the latter being the maximum load supported by the system.

TORRES (2009), when comparing two supports, bamboo and PVC, in anaerobic reactors for the treatment of cassava wastewater, obtained similar results in both reactors, increasing the efficiency of $89.6 \%$ for the organic load of $3.05 \mathrm{gL}^{-1} \cdot \mathrm{d}^{-1}$.

The results obtained in this study were higher than those found by COLIN et al. (2006) and KUCZMAN et al. (2007) and similar to those found by TORRES (2009). Compared with KUCZMAN et al. (2007), it is observed that the use of supports enabled the application of higher loads, and the removal of TVS of $92.56 \%$ to the organic load of $5,601 \mathrm{gL}^{-1} \cdot \mathrm{d}^{-1}$.

According to DE LA RUBIA et al. (2006), reduction of volatile solids is commonly used to measure the performance of the anaerobic digestion processes where the total solids content of volatiles is used as an indicator of the amount of organic matter present in the effluent. Thus, the results for the parameter removal of TVS are in agreement with the findings regarding the removal of organic matter, suggesting a high capacity of organic matter removal in the systems and application of high loads.

Regarding the efficiency of reactors for the production of biogas as a function of organic matter removal, it can be seen that the results obtained by the Tukey's test, did not differ statistically, presenting similar results of the reactors, as shown in Figure 2 (d).

For the last three organic loads applied, there was a trend for the maintenance of biogas as a function of COD removed, yielding to load of $5.601 \mathrm{gCOD} \cdot \mathrm{L}^{-1} \cdot \mathrm{d}^{-1}$ yields of 0.559 and

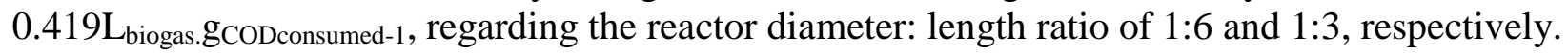

COLIN et al. (2006), when working with the anaerobic treatment of cassava wastewater in reactor with bamboo as support and volume of 6.52 liters, obtained yields of $0.54,0.39,0.51,0.44$, $0.40,0.33$ and $0.36 \mathrm{~L}_{\text {biogas.g }}$ (CoDconsumed-1, with daily supply loads of $1.1,2.3,3.8,5.3,7.3$, 9.6 and $11.8 \mathrm{~g} . \mathrm{L}^{-1} \cdot \mathrm{d}^{-1}$ respectively, and some of the loads studied by these authors are similar to those applied in this paper.

BOONAPATCHAROEN et al. (2006), working with a fixed bed anaerobic reactor in the treatment of effluent from the processing of cassava, obtained biogas productions of $0.25,0.22$, $0.24,0.33,0.35$ and $0.32 \mathrm{~L}_{\text {biogas. }}$. CoDconsumed $^{-1}$ for the daily loads of $1,2,3,4,5$ and $6 \mathrm{gL}^{-1} \mathrm{~d}^{-1}$, respectively.

KUCZMAN et al. (2007), when evaluating a continuous flow monophasic reactor for the treatment of cassava wastewater, achieved yields of $0.48,0.81$ and $0.605 \mathrm{~L}_{\text {biogas }}$. gcoDconsumided $^{-1}$ for loads of 1.28, 1.57 and 2.96g. $\mathrm{L}^{-1} . \mathrm{d}^{-1}$, respectively.

Comparing the results obtained in this study regarding the specific production of biogas with the literature, it is observed that they were similar to those obtained by COLIN et al. (2006) and 
KUCZMAN et al. (2007) and higher than those found by BOONAPATCHAROEN et al. (2006). These two authors worked with anaerobic treatment of effluent from cassava starch in a monophasic reactor.

\section{Behavior of the reactor according to the VA/TA ratio}

Analyzing the results obtained for VA/TA relation by bifactorial ANOVA, working with the average values $\pm 95 \%$ of confidence interval $(\mathrm{CI})$, significant interaction effect $(\mathrm{p}<0.05)$ was obtained, suggesting that the diameter: length ratios of the reactors and the loads applied influenced in this response variable, as can be seen in Figure 3.

Differences between the averages were evaluated by the Tukey's test $a$ posteriori adopting the level of $5 \%(p<0.05)$ of significance.

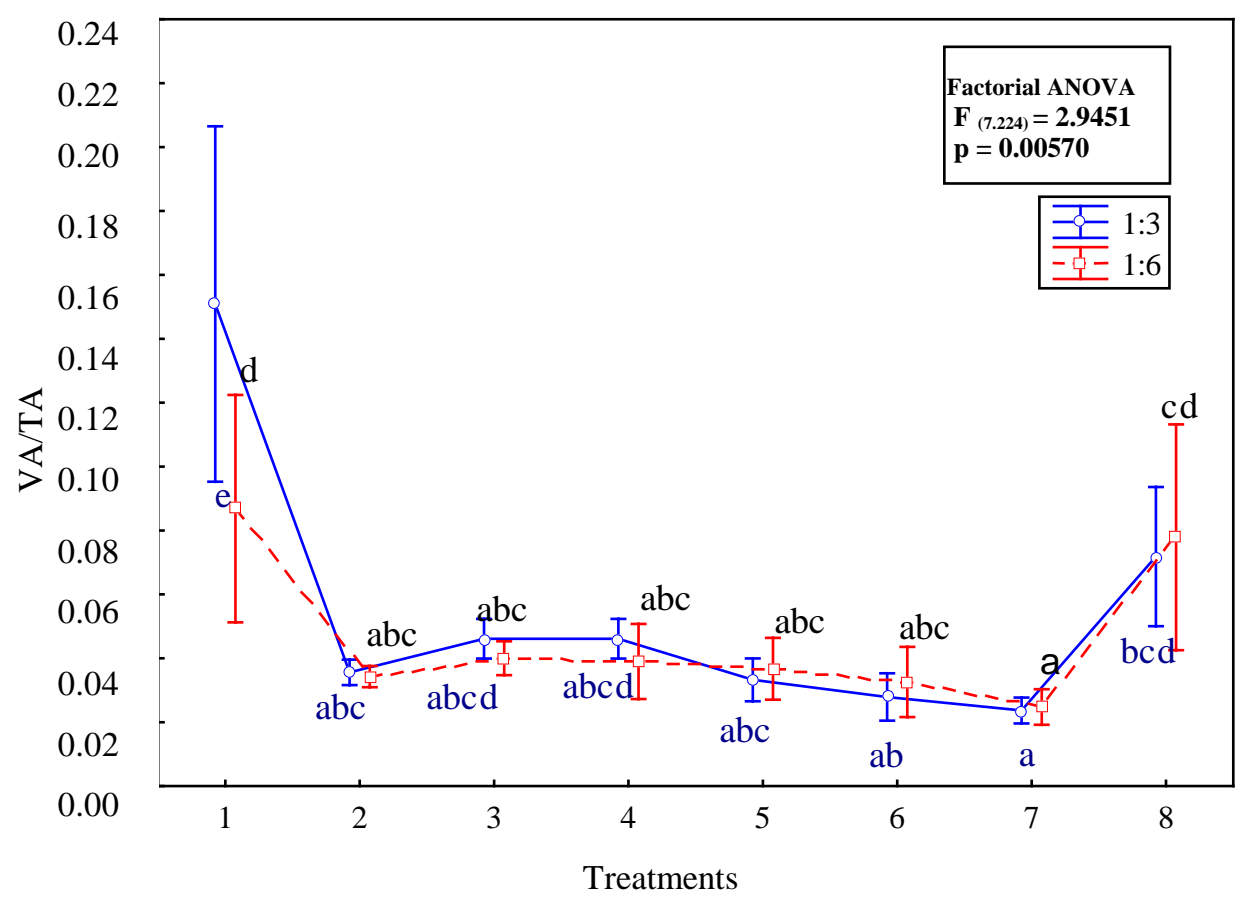

* Different letters indicate significant differences $(\mathrm{p}<0.05)$ by Tukey’s test a posteriori.

FIGURE 3. VA/TA ratio values obtained for different loads and reactors.

Figure 3 shows that the results obtained by the Tukey's test a posteriori for the VA/TA parameter, demonstrate the occurrence of statistically significant differences between the reactors and between treatments, only for the load of $0.519 \mathrm{~g}_{\mathrm{COD}} \cdot \mathrm{L}^{-1} \cdot \mathrm{d}^{-1}$ (treatment 1 ), where the values were 0.0868 and 0.1508 , for reactors with the diameter: length ratio of $1: 6$ and $1: 3$, respectively.

It is also observed, in Figure 3, a small increase in the VA/TA ratio for the last organic load applied, 5.601g $\mathrm{gOD}_{\mathrm{CO}} \cdot \mathrm{L}^{-1} \cdot \mathrm{d}^{-1}$, due to results obtained from this treatment present a high standard error as compared to those of other applied loads. However, by the Tukey's test, these results do not show statistically significant differences when compared with the other treatments.

Regarding the $5.601 \mathrm{~g}_{\mathrm{COD}} \cdot \mathrm{L}^{-1} \cdot \mathrm{d}^{-1}$ load, results found for the VA/TA ratio were 0.0778 and 0.0718 , for the reactor diameter: length ratio of $1: 6$ and $1: 3$, respectively.

According to LEIFELD et al. (2009), the VA/TA ratio is an important indicator of stability of the anaerobic digestion process and values equal or above 0.8 indicate system collapse. SILVA (1977) suggests that the total alkalinity and volatile acidity (VA/TA) ratio be less than 0.5 ensuring the stability of an anaerobic system.

In this study, the results were less than 0.1 for the applied loads, except the initial load $\left(0.519 \mathrm{~g}_{\mathrm{COD}} \cdot \mathrm{L}^{-1} \cdot \mathrm{d}^{-1}\right)$, indicating stability of the systems. 
KUCZMAN et al. (2007) evaluated a continuous flow monophasic reactor for the treatment of cassava wastewater, and obtained values of VA/TA from 0.14 to 0.30 .

When treating the cassava wastewater in an anaerobic fixed bed, BOONAPATCHAROEN et al. (2006) obtained values of VA/TA from 0.69 to 0.94 , applying organic loads ranging from 1 to 6g. $\mathrm{L}^{-1} \cdot \mathrm{d}^{-1}$.

DIAS et al. (2008), evaluating the stability of a monophasic anaerobic reactor for the treatment of cassava wastewater, verified the existence of a behavior inversely proportional between the VA/TA ratio and biogas production, obtaining values of $0.298,0.211,0.265$ and 0.776 for VA/TA when applying organic loads of 1.28, 1.57, 2.68 and $2.93 g_{\mathrm{COD}} \cdot \mathrm{L}^{-1}$.day ${ }^{-1}$. According to the authors there was a decrease of biogas production and destabilization of the system for VA/TA ratios above 0.3 .

The results obtained in this study were lower than the results obtained by the authors mentioned; suggesting that the reactors performed in stable organic loads and subjected to higher loads can also be studied.

\section{CONCLUSIONS}

According to the results obtained in this study, it can be concluded that:

- The different reactor diameter: length ratios, filled with bamboo as support, did not affect their performance for the removal of COD, TS and TVS for applied organic loads;

- Both reactors showed stable behavior regarding the VA/TA ratio for all evaluated loads;

- Reactors tended to maintain the production of biogas as a function of COD consumed for the last three applied organic loads, indicating that the systems are capable of withstanding higher organic loads;

\section{ACKNOWLEDGEMENTS}

CNPq for financial support.

\section{REFERENCES}

ABREU, S. B.; ZAIAT, M. Desempenho de reator anaeróbio-aeróbio de leito fixo no tratamento de esgoto sanitário. Revista Engenharia Sanitária Ambiental, São Paulo, v.13, n. 2, p. 181-8, abr./jun. 2008,

APHA; AWWA; WEF. Standard methods for the examination of water and wastewater. 21th ed. Washington, 2005.

BOONAPATCHAROEN, N.; MEEPIAN, K.; CHAIPRASERT, P.; TECHKARNJANARUK, S. Molecular of microbial population dynamics operations periods of anaerobic hybrid reactor treating cassava starch wastewater. Microbial Ecology, Bangkok, v. 54, p. 21-30, dec. 2006.

BORGES, A, C.; PEREIRA, P.D.A.; DE MATOS, A. T.. Partida de um reator anaeróbio horizontal para tratamento de efluentes do processamento dos frutos do cafeeiro. Revista de Engenharia Agrícola, Jaboticabal, v. 29, n. 3, p. 661-669, out/dez 2009.

CHERNICHARO C. A. L. Princípios do tratamento biológico de águas residuárias, reatores anaeróbios. 2. ed. Belo Horizonte: Departamento de Engenharia Sanitária e Ambiental, UFMG, 2007.

COLIN, X.; FARINET J.L.; ROJAS, O.; ALAZARD, D. Anaerobic treatment of cassava starch extraction wastewater using a horizontal flow filter with bamboo as support. Bioresource Technology, Colombia, v. 98, p. 1602-1607, set. 2006. 
DE LA RUBIA, M.A.; PEREZ, M.; ROMERO, L.I.; SALES, D. Effect of solids retention time (SRT) on pilot scale anaerobic thermophilic sludge digestion. Process Biochemistry, London, v. 41, p.79-86, 2006.

DIAS, A. R. P.; KUCZMAN, O.; GOMES, S. D.; TAVARAES, M. H. F.; TORRES, D. G. B.; ALCÂNTARA, M. S. Stability evaluation for a manipueira anaerobic reactor in function of volatile acidity and total alkalinity ratio and biogas production. In: TALLER Y SIMPOSIO

LATINOAMERICANO DE DIGESTIÓN ANAEROBIA, 9., 2008, Isla de Pascua. Anais... Isla de Pascua: Universidad de La Frontera, 2008. p. 991-994.

FIA, F. R.; BORGES, A. C.; DE MATOS, A. T.; DUARTE, I. C. S.; FIA, R.; DE CAMPOS, L. C.. Development of biofilm in anaerobic reactors treating wastewater from coffee grain processing. Revista Brasileira de Engenharia Agrícola e Ambiental, Campina Grande, v. 14, n. 2. p. 210-217, 2010 a.

FIA, R.; DE MATOS, A. T.; DE MATOS, M. P.; ABREU, E. C.; FIA, F. R. L.. Tratamento das águas do processamento dos frutos do cafeeiro em filtro anaeróbio seguido por sistema alagado construído: I - Remoção de matéria orgânica. Revista de Engenharia Agrícola, Jaboticabal, v. 30, n. 6, p. 1191-1202, nov/dez 2010 b.

GIUSTINA, S. V. D.; MIRANDA, L.A. S.; MONTEGGIA, L.O. Remoção de matéria orgânica e sólidos suspensos por nova configuração de biofiltro aeróbio submerso no pós-tratamento de efluente de reator UASB. Revista de Engenharia Sanitária e Ambiental, Rio de Janeiro, v. 15, n. 3, p. 257-266, jul/set 2010.

KUCZMAN, O.; TORRES, D. G. B.; DAMASCENO GOMES, S.; TAVARES, M. H. F.; ALCANTARA, M. S.. Tratamento anaeróbio de efluente de fecularia em reator horizontal de uma fase. Revista Raízes e Amidos Tropicais, Botucatu, v.3, p. 5-10, 2007.

KUCZMAN, O.; DAMASCENO GOMES, S.; TAVARES, M. H. F.; TORRES, D. G. B.; ALCANTARA, M. S.. Produção específica de biogás a partir de manipueira em reator de fase única. Revista Engenharia Agrícola, Jaboticabal, v.31, n. 1, p. 143-149, jan./fev. 2011.

LEIFELD, V.; RIVAS, L. M. C. G.; BARANA, A. C.. Comparação entre filtros biológicos anaeróbios para o tratamento de efluentes de abatedouro com diferentes sistemas de alimentação. Revista de Engenharia e Tecnologia, Ponta Grossa, v.1, p. 102, 2009.

LEITE, V. D.; LOPES, W. S.; SOUZA, J. T.; PRASAD, S.; SILVA, S. A.. Tratamento anaeróbio de resíduos sólidos orgânicos com alta e baixa concentração de sólidos. Revista Brasileira de Engenharia Agrícola e Ambiental, Campina Grande, v. 13, n. 2. p. 190-1967, 2009.

LIU, C.; YUAN, X.; ZENG, G.; LI, W.; LI, J. Prediction of methane yield at optimum pH for anaerobic digestion of organic fraction of municipal solid waste. Bioresource Technology. Colombia, v. 99, p. 882-888, 2008.

ORTIGARA, A. R. C.; SANT’ANNA, F. S. P.; BENTO, A. P.; SEZERINO, P. H.. Tratamento de efluente vinícola empregando biofiltro aerado submerso em escala laboratorial. Revista de Engenharia Ambiental, Espírito Santo do Pinhal, v. 7, n. 2. p. 041-054, abr./jun. 2010.

RODRIGUES, L.S.; SILVA, I. J.; ZOCRATO, M. C. O.; PAPA, D. N.; SPERLING, M. V.; OLIVEIRA, P. R.. Avaliação de desempenho de reator UASB no tratamento de águas residuárias de suinocultura. Revista Brasileira de Engenharia Agrícola e Ambiental, Campina Grande, v. 14, n. 1. p. 94-100, 2010.

PINTO, P. H. M.; CABELLO, C. Tratamento de efluentes líquidos de fecularia em biodigestores anaeróbios de fluxo ascendente. Revista Raízes e Amidos Tropicais, Botucatu, v 3, , p. 1-4. 2007.

RIBAS, M. M. F.; BARANA, A. C.. Start-up adjustment of a plug-flow digester for cassava wastewater (manipueira) Treatment. Science Agricola, Piracicaba, v. 60, n. 2, p. 223-229, abr./jun. 2003. 
SANTOS, A. C.; OLIVEIRA, R. A.. Tratamento de águas residuárias de suinocultura em reatores anaeróbios horizontais seguidos de reator aeróbio em batelada sequencial. Revista de Engenharia Agrícola, Jaboticabal, v. 31, p. 781-794, jul./ago. 2011.

SILVA, M. O. S. A. Análise físico-quimicas para o controle das estações de tratamento de esgoto. São Paulo: CETESB, São Paulo, 1977. p. 226.

TORRES, D. G. B. Meios Suporte no tratamento da manipueira. 2009. Dissertação (Mestrado em Engenharia Agrícola) - Universidade Estadual do Oeste do Paraná , UNIOESTE, - Cascavel, 2009.

VON SPERLING, M. V. Princípios do tratamento biológico de águas residuárias - Princípios básicos do tratamento de esgotos. Belo Horizonte: Departamento de Engenharia Sanitária e Ambiental, Universidade Federal de Minas Gerais, 1996. v. 2, p. 211.

QIU, L.; ZHANG, S.; WANG, G.; DU, M. Performances and nitrification properties of biological aerated filters. Bioresource Technology, Essex, v. 101, p. 7245-7251, 2010.

XIE, B.; YI LV, B.; HU, C.; LIANG, S. B.; TANG, Y.; LU, J. Landfill leachate pollutant removal performance of a novel biofilter packed with mixture medium. Bioresource Technology, Essex, v. 101, n. 20, p. 7754-7760, 2010. 